\title{
ANALYSIS OF OBSERVATIONS BASED ON THIRTEEN YEARS OF PARTICIPATING IN THE FEEDERWATCH PROJECT
}

Diether P. Peschken

217 Lockwood St.

Winnipeg, MB R3N 1S1

peschken@outlook.com

The FeederWatch project is organized by Bird Studies Canada. Participants count the maximum number of each bird species seen at one time at the feeder and the immediate surroundings such as the backyard. Only birds that are attracted to food or water provided are counted. Birds that only fly over the count site (term used by Bird Studies Canada for the observation area) are not recorded. Birds are counted on two consecutive days (called two-day observation periods) as often as every week (for online data entry) or every two weeks (for paper data entry). Given these criteria, it is up to the observer how often birds are counted. The FeederWatch observation period begins in November and ends in April. My count site consisted of

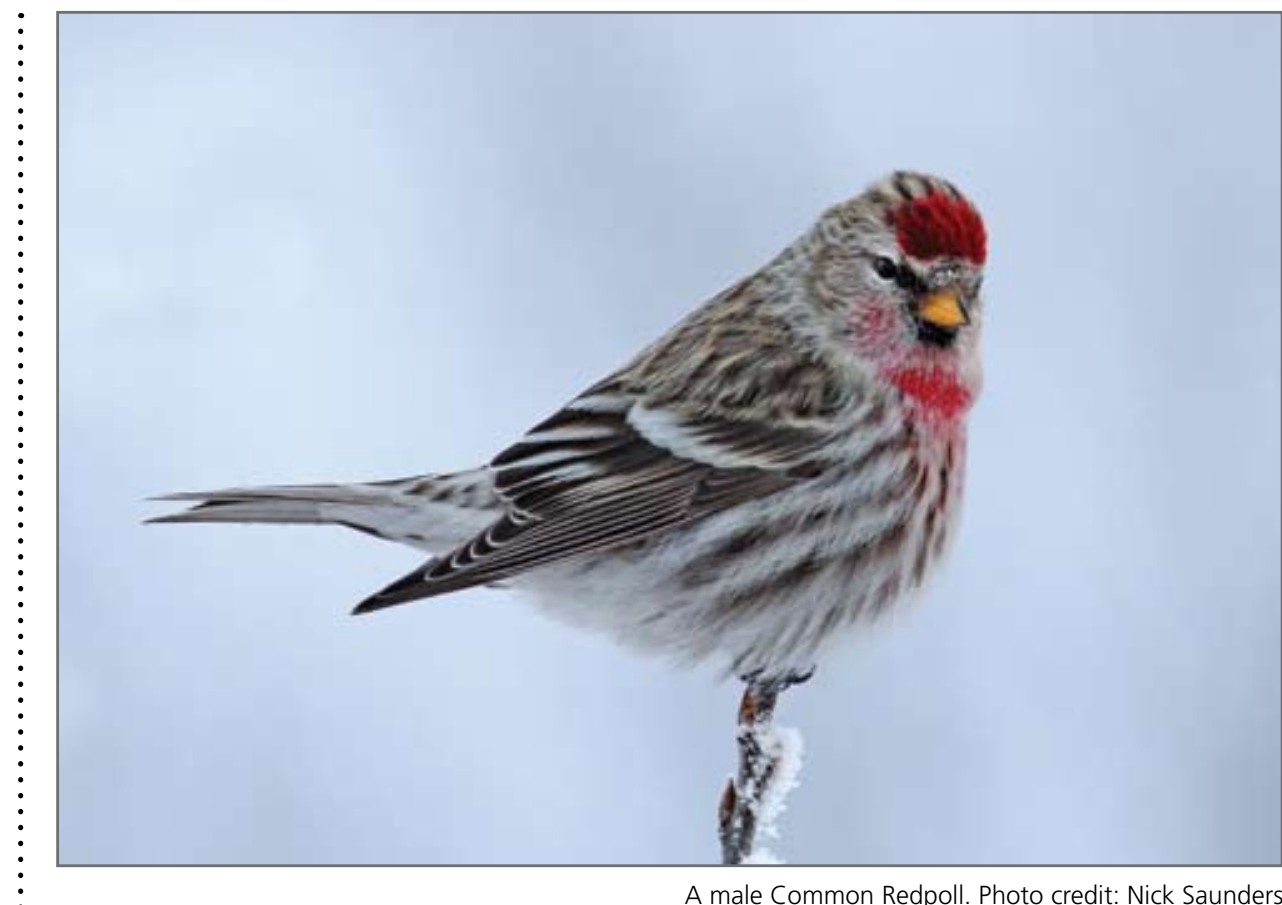

a backyard in the Lakeview neighbourhood of Regina, Saskatchewan. The yard was landscaped with perennials, various bushes and trees. I collected observations for 13 years, from

A male Common Redpoll. Photo credit: Nick Saunders
FIGURE 1: The number of individual birds and the number of species, both presented as averages over the number of two-day observation periods in each of the 13 years.

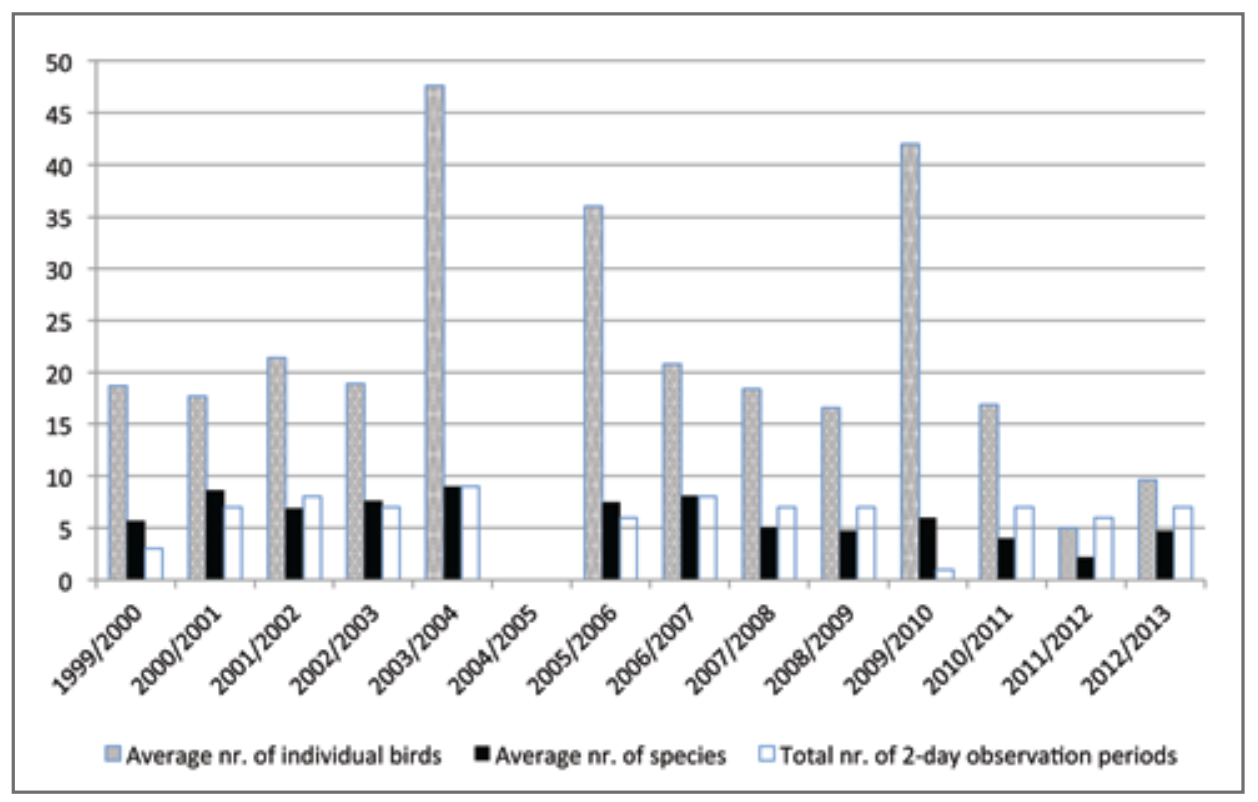

1999 to 2013, with the exception of the 2004-05 winter. I provided black sunflower and nyjer seeds and a mixture of seeds, chunks of beef fat or suet, and sometimes shelled peanuts. Until 2003-04, I used a platform feeder and tube feeder. But when a cat climbed on to the feeder, I switched to a hopper feeder, perched on top of a steel post 180 $\mathrm{cm}$ high with an outside diameter of $16 \mathrm{~mm}$. Over the 13 years, I counted the birds on 83 two-day observation periods.

At the beginning of the project, only one or two squirrels, mostly Eastern Fox Squirrels (Sciurus niger) and Eastern Gray Squirrels (Sciurus carolinensis) were seen in a year. But by the end, up to four squirrels were observed at once. Squirrels had no trouble to climb up the thin poles. Therefore, in 2007 I installed "squirrel buffers" (Homestead Gardener Equipment Co., Juneau, WI, USA) that prevented squirrels 
Table 1. The number of individuals and the number of observation periods out of a total of $\mathbf{8 3}$ when a species was recorded at the feeding station.

\begin{tabular}{|c|c|c|}
\hline & \multicolumn{2}{|c|}{ OBSERVATION PERIODS } \\
\hline & INDIVIDUALS & \\
\hline SPECIES & & \\
\hline $\begin{array}{l}\text { Rock Pigeon } \\
\text { (Columba livia) }\end{array}$ & 21 & 8 \\
\hline $\begin{array}{l}\text { Downy Woodpecker } \\
\text { (Picoides pubescens) }\end{array}$ & 81 & 57 \\
\hline $\begin{array}{l}\text { Hairy Woodpecker } \\
\text { (Picoides villosus) }\end{array}$ & 37 & 33 \\
\hline $\begin{array}{l}\text { Northern Flicker } \\
\text { (Colaptes auratus) }\end{array}$ & 24 & 21 \\
\hline $\begin{array}{l}\text { Black-billed Magpie } \\
\text { (Pica hudsonia) }\end{array}$ & 17 & 11 \\
\hline $\begin{array}{l}\text { Black-capped Chickadee } \\
\text { (Poecile atricapillus) }\end{array}$ & 38 & 28 \\
\hline $\begin{array}{l}\text { Red-breasted Nuthatch } \\
\text { (Sitta canadensis) }\end{array}$ & 142 & 76 \\
\hline $\begin{array}{l}\text { White-breasted Nuthatch } \\
\text { (Sitta carolinensis) }\end{array}$ & 65 & 57 \\
\hline $\begin{array}{l}\text { Brown Creeper } \\
\text { (Certhia Americana) }\end{array}$ & 16 & 16 \\
\hline $\begin{array}{l}\text { American Robin } \\
\text { (Turdus migratorius) }\end{array}$ & 2 & 2 \\
\hline $\begin{array}{l}\text { Dark-eyed Junco } \\
\text { (Junco hyemalis) }\end{array}$ & 52 & 30 \\
\hline $\begin{array}{l}\text { Common Grackle } \\
\text { (Quiscalus quiscula) }\end{array}$ & 1 & 1 \\
\hline $\begin{array}{l}\text { House Finch } \\
\text { (Carpodacus mexicanus) }\end{array}$ & 216 & 56 \\
\hline $\begin{array}{l}\text { Red Crossbill } \\
\text { (Loxia curvirostra) }\end{array}$ & 4 & 1 \\
\hline $\begin{array}{l}\text { Purple Finch } \\
\text { (Carpodacus purpureus) }\end{array}$ & 5 & 1 \\
\hline $\begin{array}{l}\text { Common Redpoll } \\
\text { (Acanthis flammea) }\end{array}$ & 224 & 19 \\
\hline $\begin{array}{l}\text { Hoary Redpoll } \\
\text { (Acanthis hornemanni) }\end{array}$ & 7 & 5 \\
\hline $\begin{array}{l}\text { Pine Siskin } \\
\text { (Spinus pinus) }\end{array}$ & 76 & 21 \\
\hline $\begin{array}{l}\text { American Goldfinch } \\
\text { (Spinus tristis) }\end{array}$ & 1 & 1 \\
\hline $\begin{array}{l}\text { House Sparrow } \\
\text { (Passer domesticus) }\end{array}$ & 772 & 76 \\
\hline
\end{tabular}

from climbing up to the feeders.

I identified 20 species of birds that visited the feeders over the 13 years (Table 1). Some visitors I discouraged. Rock Pigeons fed almost exclusively on the ground on spilled seeds. I placed chicken wire on the ground underneath the feeder preventing them from feeding. Black-billed Magpies fed exclusively on chunks of beef fat. I placed a small board over the beef fat to prevent magpies from reaching the fat.

Purple Finches were recorded only once, in a group, on March 12, 2002. A single Common Grackle appeared on November 13, 2005, probably a late migrant. Similarly, a single American Goldfinch appeared in its winter plumage on February 10, 2007, perhaps an early migrant. On March 31, 2003, and again on the same date in 2007, a single American Robin came to the feeder. A few robins are known to overwinter in Regina (personal communication and my own observations). Red Crossbills were observed only once, on April 4, 2013. The most numerous and regular visitors were House Sparrows. A total of 772 individuals were counted on 76 out of the 83 observation periods. Downy Woodpeckers, House Finches and Red-and White-breasted Nuthatches were also quite numerous and regular. The Common Redpoll was the second most numerous visitor over the years, but quite erratic. It appeared at the feeding station during only 19 of the 83 two-day feeding periods. In fact, more than half (121) appeared in only one winter, 2003-04. Hairy Woodpeckers and Northern Flickers were regular visitors from 1999-2000 to 2007-08.
A total of 35 Hairy Woodpeckers and 26 Northern Flickers were counted in those eight winters with together 51 observation periods. But in the five following winters from 2008-09 until 2012-13, I counted only two Hairy Woodpeckers and one Northern Flicker in 28 observation periods.

Over the years, the number of individual birds and the number of species varied greatly. Because the number of two-day observation periods varied from month-tomonth and year-to-year, I averaged the number of individuals and species over the number of two-day observation periods for each year (Fig. 1). The average number of individuals observed at the feeder varied from a low of six in the 201112 winter to a high of 47.6 in $2003-$ 04 . The average number of species observed at the feeders ranged from 2.2 in 2011-12 to a high of nine in 2003-04.

Aside from providing some solid numbers, which allowed the above analysis, it was a sheer pleasure to watch the variety of birds, active on even the coldest days of winter.

Acknowledgements: I thank my daughter, Wiebke Peschken, and an anonymous reviewer for many helpful editorial comments and improvements, and my son-in-law Doug Strang for producing Fig. 1.

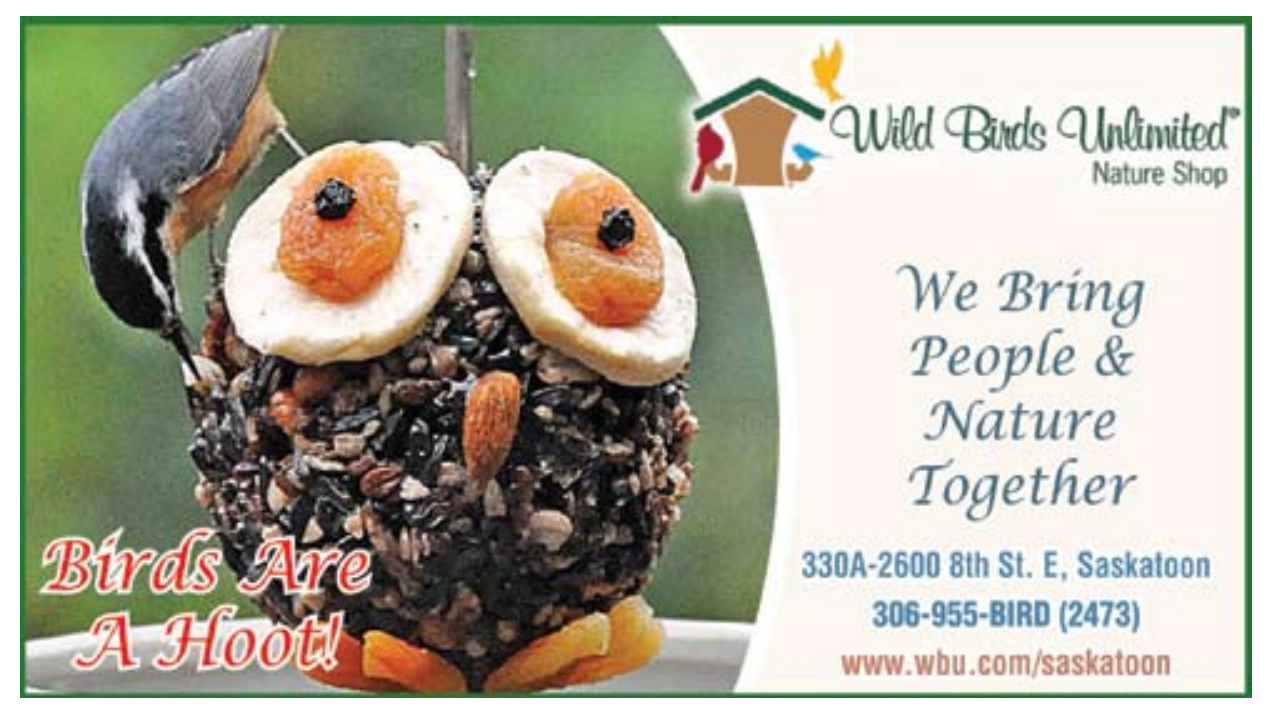

